\title{
Physics teachers' beliefs on ICT integration at secondary school in Indonesia and Philippines
}

\author{
Dwi Sulisworo ${ }^{1}$, Ulaya Ahdiani ${ }^{2}$ \\ ${ }^{1}$ Physics Education, ${ }^{2}$ English Letters \\ Ahmad Dahlan University \\ Yogyakarta, Indonesia \\ dwi.sulisworo@uad.ac.id
}

\author{
Emma S. Lirag ${ }^{3}$ \\ ${ }^{3}$ Education Faculty \\ Nueva Caceres University \\ Naga City, Philippines \\ emslirag@yahoo.com.ph
}

\begin{abstract}
The popularity of physics, as well as the interest in the field, seems to be declining in the school worldwide from year to year. Teachers are likely to hold beliefs about teaching and learning and use of ICT tools which are additional instruments considered in the teaching and learning practice. The increase in ICT development gives wide opportunities in its use to improve the learning performance. The study aims to find out a realistic picture of the teaching-learning constraints of teachers in the use of ICT especially those with certain beliefs in its use. It is the qualitative research using triangulation method. This study involved physics teachers, principals, and physics students from Indonesia and Philippines. The result showed that almost all physics teachers in Indonesia and Philippines belief that ICT has many benefits to enhance learning. The supporting regulation from school management is needed to encourage the teacher to use ICT in their learning activities.
\end{abstract}

Keywords: teacher belief, mobile technology, learning, school innovation

\section{INTRODUCTION}

ICT development is growing rapidly. ICT is the driving factor for the growth of various sectors of life in many countries $[1,2]$. The influence of this technology in learning is also significant for the improvement of learning performance [3, 4]. Many studies have shown the success of the use of ICT in learning to improve learning performance in various education aspects. These studies show there are positive impacts at the level of the class [5, 6], community [7], and a larger area [3]. But it is undeniable that there is still controversy by teachers related to the use of ICT, especially mobile technology in schools. On the other hand, teachers' ICT literacy will also determine how ICT can be used optimally in learning at school $[8,9]$. Teachers have not fully believed to use ICT in learning.

The interest of students in studying physics decreases from time to time. This phenomenon occurs in various countries around the world. This trend requires anticipation included in the learning interaction between teachers, students, and material through certain media [10]. Utilization of ICT in physics education is done for a variety of learning activities such as research laboratories through the use of specific models, simulations and animations for certain experiments in order to improve understanding of a concept or the laws of physics, material delivery or learning strategies, as well as a learning management system. On the daily school activities, sometime school does not have a policy for the utilization of this technology. There are schools which do not allow an opportunity for teachers and students to use
ICT in learning by prohibiting students to carry their gadgets in school.

The success of the use of ICT in learning physics is determined by teacher beliefs about the benefits of ICT in learning. This confidence will drive the teachers to improve their skills in ICT, to decide the learning strategy using ICT, to motivate students, and to manage the interaction of learning [9]. Nowadays, students as a digital native have good literacy on ICT. Students will be easy to adapt the ICT based learning when provided a conducive environment and supported by school $[11,12]$. Thus teachers' confidence will be crucial in the process of adoption of ICT in classroom learning.

From the background, the identified problem are teachers have not fully believed to use ICT in learning, some school does not establish the policy of using ICT on learning at school, and some school and teacher do not allow students to bring their gadget at school. Based on the problem identification, the problem is how the teachers' belief in using ICT on learning to enhance student learning performance. The study aims to find out a realistic picture of the teaching-learning constraints of teachers in the use of ICT especially those with certain beliefs in its use. The study must be able to answer the following questions:

a. Do teachers have proper ICT literacy?

b. Do teachers believe that integrating ICT in teaching and learning will improve learning performance?

c. What are the teachers' activities in their classroom in using ICT in the teaching process? 


\section{LITERATURE REVIEW}

\section{A. Teacher belief}

Teacher beliefs play critical roles in technology integration [13]. Additionally, one can argue that constructivist pedagogical belief of teachers about teaching and learning are a significant factor in determining patterns of technology use in classrooms. Teachers who held constructivist pedagogical beliefs successfully integrated technology into instruction. Teachers who have strong constructivist pedagogical belief were more likely to use technology in the classroom than teachers who have traditional pedagogical belief.

Teacher who held constructivist-oriented pedagogical beliefs asked students to complete small research projects using assigned websites, and conducted group discussions using some gadget [6]. Students also worked well together and made meaning of information or data using technology that was seen by students as an information resource, data collection tool, simulation tool, and scaffolding tool. These studies suggest that teachers who hold constructivist-oriented pedagogical beliefs can help students think, interact, and reflect using technology in learning environments [4, 7]. These teachers can also overcome barriers to integrating technology into instruction for effective teaching [9]. In summary, the correlation between teacher pedagogical beliefs and teaching activities when using technology varies among studies, underscoring the importance of considering the factors associated with teacher decisions to employ technology in their classrooms.

\section{B. Teaching activities for technology integration}

The use of technology in classrooms can be defined and determined in various ways. For instance, who constructed a scale that determined how often teachers used computers in a classroom, classified activities using computers during teaching into the following eight types: encouraging collaborative learning; using computers for differentiation activities; encouraging students to improve their skills; requiring students to complete assignments on a computer; using a computer as a demonstration tool; using a computer as an instruction tool; encouraging students to search for information on the Internet; and, teaching students about the possibilities of computer use [10]. Except for enhancing student computer skills, these teaching activities involve lecture-based or transmission oriented activities and constructivist- or learner-based activities [7,9]. The former reveals a phenomenon in which teachers use computers to present instructional material, while the latter is an active situation in which students are encouraged to participate in learning tasks, including collecting, analyzing, and presenting information [11.

The contemporary issue of technology integration is generally focused on facilitating student development of conceptual understanding through instructional processes, during which teachers require active engagement with complex academic content [6, 14]. During constructivist learning processes, teachers act as coaches or facilitators rather than lecturers. During learning, students use indepth questioning to acquire information, and interact with classmates. When students work in small groups, they can contribute to a common understanding and develop their verbal and social skills. Differing from individual learning, students working in small groups are familiar with sharing personal opinions, and know where to find information and how to identify data.

\section{Factors associated with technology integration}

The factors influencing teacher decisions about technology integration have been identified as teacher professional development and training, administrative support, positive school environment, adequate technological resources, technology access, technical assistants, adequate planning time, sustained funding for technology, instructional styles, attitudes toward learning, pedagogical beliefs, and personal characteristics $[3,4]$. Additionally, the attitude of the principal, colleague influence, and parental involvement were identified as factors influencing teacher technology integration. Factors influencing technology adoption were responding to external requests and expectations of others, increasing student attention, using the basic functions of technology, relieving physical fatigue, class preparation and management, and using enhanced technology functions. Many external factors, such as teacher training and availability of technology, are likely not problems as many technology-based programs have been funded by government $[5,7,9]$. Therefore, pressure to teach all textbook content and help students achieve high exam scores may also affect technology use.

\section{Methodology}

It is the qualitative research using triangulation method. Schools which used in this study were selected using purposive cluster sampling. This study involved physics teachers, headmasters/ principals, and physics students each from Indonesia and Philippines.

\section{A. Quesionnaires}

Questionnaires were answered by teachers of physics subject. The questionnaires are consist of the derivative of the research question, as presented in table 1 below. 
TABLE I. QUESTIONNAIRE STRUCTURE

\begin{tabular}{l}
\hline Do teachers have proper ICT literacy? \\
\hline Which application has teacher mastered? \\
Which gadget does teacher use to support his/ her \\
teaching and learning activities? \\
Does teacher ever undergo ICT training or education \\
regularly?
\end{tabular}

Do teachers believe that integrating ICT in teaching and learning will improve learning performance?

Does physic teacher allow student to use their gadget (smartphone/ tablet/ laptop) in their classroom?

Is there an administrative policy in the school process in the integration of ICT on teaching and learning process?

What internet connection is available in school?

What are the teachers' activities in their classroom in using ICT in the teaching process?

What learning management system (or other system to support learning) used in physics learning activities?

What activities are used to support Physics learning?

How many times does teacher use ICT in Physics learning per semester?

\section{B. Participants}

The data of this research are collected from 3 schools ( 1 from Philippines, and 2 from Indonesia) as a case study of this observation. Table 2 shows the participant profile.

TABLE II. PARTICIPANT PROFILE

\begin{tabular}{llll}
\hline Participants & Indonesia & Philippines & Sum \\
\hline Student & & & \\
\hline Male & 48 & 0 & 48 \\
Female & 60 & 36 & 96 \\
\hline Sub total & 108 & 36 & 144 \\
\hline Teacher & & & \\
\hline Male & 5 & 0 & 5 \\
Female & 2 & 2 & 4 \\
\hline Sub total & 7 & 2 & 9 \\
\hline Principal & & & 2 \\
\hline Male & 2 & 0 & 3 \\
Female & 2 & 1 & 5 \\
\hline Sub total & 4 & 1 & 158 \\
\hline Total & 119 & 39 & \\
\hline
\end{tabular}

\section{A. Do teachers have proper ICT literacy?}

Information and communication technology (ICT) literacy is very important for students as they make progress at school and is in an environment where information technology will be ubiquitous. Literacy owned by students will be well-developed when teachers also have good literacy. To determine the ICT literacy of teachers can be seen from some symptoms or indicators. There are three indicators to measure ICT literacy of physics teachers, (1) the type of application used in teaching, (2) the type of gadget, (3) the intensity of ICT training given to the teachers. These indicators show the trend of changing from computer skills to network setting.

From students and teachers statement, it is found that word processor application, such as Microsoft Words, is the most frequent application used in the classroom. This statement is also supported by the Headmaster that teachers apply $3-5$ applications in the use of ICT in teaching and learning. Those applications are mostly words and numbers processor, and presentation. However, some students claim that some teachers in Indonesia and the Philippines use video/ photo editing in teaching and learning process.

Meanwhile, laptop and PC are the most frequent gadgets used in teaching and learning. There are no teachers found using smartphone or tablets to teach in the classroom, even though teachers in both countries are using smartphone and tablets personally. In both countries, physics teachers do not get proper training of using ICT in teaching and learning process. They independently learn the applications to use them in teaching. This becomes the reason why the use of ICT in physics teaching and learning process is low and seems to be not important to increase their performance.

\section{B. Do teachers believe that integrating ICT in teaching and learning will improve learning performance?}

Access support in integrating ICT in teaching and learning process can be seen from gadgets used, multimedia and LMS used, and internet connection. The most frequent gadgets used by students are smartphone, and some students have more than one smartphones. Meanwhile teachers use PC more than use smartphones to internet access, although the numbers of teachers using smartphones are high. From that fact, we can conclude that both teachers and students have good virtual access. The internet connection is generally using cellular provider attached in their smartphones. There is no school found providing $\mathrm{Wi}-\mathrm{Fi}$ connection for their students and teachers.

Integrating ICT in teaching and learning, both teachers and students needs supporting policy. The policy could be in the form of formal rules issued by the school about the integrating ICT in teaching and learning, and the permit to use gadgets in the classroom. Most schools do not have such assertive policy which makes teachers 
cannot ask students to use their gadgets during teaching and learning process.

\section{What are the teachers' activities in their classroom in using ICT in the teaching process?}

Mobile technology utilization on learning proved the improvement of learning environment at high school students [15]. Integrating ICT in teaching and learning process can be seen from the type of activities and the frequency of using ICT $[16,17]$. Indonesian teachers use ICT in the classroom to present teaching materials more frequent than the Philippines teachers. However, the Philippines teachers use ICT more frequent to show subject than Indonesian teachers.

From the teaching activities, it can be seen that ICT is used mainly as tools in delivering teaching materials. The use of ICT in practicum, data collecting, physics simulation, and other activities, is not clearly seen. The intensity of using ICT in teaching and learning process is still low, and it is used most often in the classroom, not in the application of mobile learning. But teachers from Indonesia use ICT on more various activities than teacher from Philippines.

\section{DISCUSSION}

The higher the level of ICT penetration in life and also in schools today has prompted intensified the use of students in the social network [18]. ICT literacy in the past decade focused on the use of computers, has now shifted on social network activity with many new skills. The ability of teachers to understand and assist students in this new environment becomes very important. The ability and belief of teachers to integrate ICT on learning at school will enable the improving of the student interaction to the new knowledge which is more easily found through social networks [19; 20]. Two important factors in deciding to apply integrating ICT in teaching and learning are school's policy and human resources [21]. Both factors will relate to the enhancing of the ICT engagement. ICT engagement dimension is associated with individual differences in behavioral and cognitive construction. From the research, it can be assumed that both Indonesian and the Philippines teachers have sufficient confidence in integrating ICT in teaching and learning physics. It can be seen from the teachers 'efforts in applying ICT in the classroom. The use of ICT in teaching and learning may vary. This happens because of several reasons, i.e.: the various level of ICT understanding of the teachers due to lack of training and the policy of the school due to the use of ICT in teaching and learning. The utilization of internet connection should be widely increased, including the usage of internet connection from the providers attached in teachers' and students' smartphones.

The teacher belief and awareness on ICT has effect to student learning performance on certain subject. It means that teacher will support student on knowledge finding and sharing to improve their understanding. Teachers in
Indonesia and Philippines show their effort to use ICT on their learning even in limited number of application type. This situation will be different if school management gives opportunity for teacher to upgrade their literacy by providing advance education or training. The shifting of the learning environment driven by the ICT innovation must be supported by management policy on its integration. School in Indonesia and Philippines has not provided proper policy yet to engage student and teacher on using ICT on learning. The principal awareness on ICT integration is very important to determine the success of teaching and learning process [22-24].

Learning management system has not been exploited in teaching in schools both in Indonesia and in the Philippines. It showed that the use of ICT is still limited. Various advantages and capabilities in ICT has not been used more intensively for e-learning, for instance. ICT tends to be used to deliver the learning content in classroom with the face-to-face interaction setting. Teachers and students have smartphones but they are not used properly as a medium for learning interactions. The limited type of interaction using ICT makes learning less productive. School cannot take the advantage of ICT for learning.

\section{CONCLUSIONS}

In general, teachers and students in Indonesia and the Philippines are already familiar with mobile technology. Almost all of them already have and use smartphone in their daily activities. On the other hand, teachers of physics belief that the use of ICT in learning will be very beneficial for a good and successful learning. This belief is demonstrated in their efforts to use it in learning activities, though still limited to the delivery of the subject matter in face to face learning interaction setting. Limitations of teachers in using ICT in various modes caused by the capability related to the rapid of ICT based application development. It is not caused by low teacher's motivation, but because of the limited opportunities for training and education to improve their ability. It is likely to be the root of the problem that the school management has not explicitly yet provided support for the integration of ICT in the learning process.

\section{Acknowledgment}

This research was supported by Ahmad Dahlan University, Indonesia and University of Nueva Caceres, Philippines under the joint research agreement for year 2016. It was coordinated by Research and Development Agency of Ahmad Dahlan University.

\section{References}

[1] S. Kemp, "Digital, Social \& Mobile Worldwide in 2015" Date of access: 21/09/2016. http://wearesocial.net

[2] D. Sulisworo, "The Contribution of the Education System Quality to Improve the Nation's Competitiveness of Indonesia," Journal of Education and Learning (EduLearn), vol 10, no 2, pp. 127-138, 2016. 
[3] M. Alqahtani, \& H. Mohammad, "Mobile Applications' Impact on Student Performance and Satisfaction," TOJET: The Turkish Online Journal of Educational Technology, vol 14, no 4, pp. 102 112, 2015.

[4] J. H. L. Koh, C. S. Chai, W. Benjamin, \& H. Y. Hong, "Technological Pedagogical Content Knowledge (TPACK) and design thinking: A framework to support ICT lesson design for 21st century learning," The Asia-Pacific Education Researcher, vol 24, no 3, pp. 535-543, 2015.

[5] F. Erdogdu, \& E. Erdogdu, "The impact of access to ICT, student background and school/home environment on academic success of students in Turkey: An international comparative analysis," Computers \& Education, vol 82, pp. 26-49, 2015.

[6] D. Sulisworo, \& F. Suryani, "The Effect of Cooperative Learning, Motivation and Information Technology Literacy to Achievement," International Journal of Learning \& Development, vol 4, no 2, pp. 58-64, 2014.

[7] N. Davidson, C. H. Major, \& L. K. Michaelsen, "Small-group learning in higher education-cooperative, collaborative, problem-based, and team-based learning: An introduction by the guest editors," Journal on Excellence in College Teaching, vol 25, pp. 1-6, 2014.

[8] B. Guennoun, \& N. Benjelloun, "How university students perceive the integration of ICT in their physics courses," IOSR Journal of Research \& Method in Education (IOSR-JRME), vol 4, no 4, pp. 1-8, 2014.

[9] J. Tondeur, A. Forkosh-Baruch, S. Prestridge, P. Albion, \& S. Edirisinghe, "Responding to challenges in teacher professional development for ICT integration in education," Journal of Educational Technology \& Society, 19(3), 110-120, 2016.

[10] M. E. Babiker, "For Effective Use of Multimedia in Education, Teachers Must Develop their Own Educational Multimedia Applications," TOJET: The Turkish Online Journal of Educational Technology, vol 14, no 4, pp. 62-68, 2015.

[11] M. Henderson, N. Bellis, M. Cerovac, \& G. Lancaster, "Collaborative Inquiry: Building Pre-Service Teachers' Capacity for ICT Pedagogical Integration," Australian Educational Computing, vol 27, no 3, pp. 69-75, 2013.

[12] R. Vanderlinde, K. Aesaert, \& J. Braak, "Measuring ICT use and contributing conditions in primary schools," British Journal of Educational Technology, vol 46, no 5, pp. 1056-1063, 2015.

[13] C. Hongboontri, \& N. Keawkhong, "School Culture: Teachers' Beliefs, Behaviors, and Instructional Practices,". Australian Journal of Teacher Education, vol 39, no 5, pp. 66-88, 2014.
[14] T. S. Safitry, T. Mantoro, M. A. Ayu, I. Mayumi, R. Dewanti, \& S. Azmeela, "Teachers' Perspectives and Practices in Applying Technology to Enhance Learning in the Classroom," International Journal of Emerging Technology on Learning - iJET., vol 10, no 3, 10-14, 2015.

[15] D. Sulisworo, \& M. Toifur, "The role of mobile learning on the learning environment shifting at high school in Indonesia," International Journal of Mobile Learning and Organisation, vol 10, no 3, pp. 159-170, 2016.

[16] D. A. Kumar, \& V. Umadevi, "Effective ICT Tools for Course Management," Journal of Engineering Education Transformations, Special Issue, pp. 276-279, 2015.

[17] V. Turel, S. Calık, \& A. Doganer, "Tertiary Students' ICT Selfefficacy Beliefs and the Factors Affecting Their ICT-Use," International Journal of Information and Communication Technology Education (IJICTE), vol 11, no 2, pp. 90-104, 2015.

[18] M. Wilson, K. Scalise, \& P. Gochyyev, "Rethinking ICT literacy: From computer skills to social network settings," Thinking Skills and Creativity, vol 18, pp. 65-80, 2015.

[19] K. Oshima, \& Y. Muramatsu, "Current situation and issues related to ICT utilization in primary and secondary education," Fujitsu Scientific and Technical Journal, vol 51, no 1, pp. 3-8, 2015.

[20] A. Menon, "Attitude of Secondary School Teachers towards ICT Literacy and Its Implications in Classroom Teaching," International Journal of Research, vol 2, no 4, pp. 789-794, 2015.

[21] S. K. Basak, \& D. W. Govender, "Development Of A Conceptual Framework Regarding The Factors Inhibiting Teachers' Successful Adoption And Implementation Of ICT In Teaching And Learning," The International Business \& Economics Research Journal (Online), vol 14, no 3, pp. 431, 2015

[22] R. Anthony, \& K. Shravan, "ICT (Information And Communication Technologies) Adoption Model For Educational Institutions," Journal of Commerce and Management Thought, vol 6, no 3, pp. 558- 570, 2015.

[23] S. S. Kim, \& S. Ahn, "An Analysis on ICT Lietracy Level of Elementary School Student according to Pricipal's Awareness of Educational Information Technology," The Journal of the Korea Contents Association, vol 16, no 2, pp. 268-276, 2016.

[24] J. Zylka, G. Christoph, U. Kroehne, J. Hartig, \& F. Goldhammer, "Moving beyond cognitive elements of ICT literacy: First evidence on the structure of ICT engagement," Computers in Human Behavior, vol 53, pp. 149-160, 2015. 